\title{
MULTICULTURAL EUROPE?*
}

\section{Ebru OĞURLU**}

\section{Abstract:}

Starting from the first years of the $21^{\text {st }}$ century, multiculturalism has emerged as one of the major research areas in the European political agenda as a result of the challenges to the modernist approach of nation building processes. Considering its various implications, this study shows the two sides of the same coin by focusing on the positive and negative connotations of this concept and tries to answer whether multiculturalismin a positive sense - is a viable policy in Europe. In this framework, the specific country examples prove the fact that recent multicultural discourses are only used as justifications for the elimination or assimilation of various sub-cultures in Europe by preserving the primacy of the dominant ones. This tendency, however, can easily impose an inward-oriented nature both on Europe as a continent and the EU as a political entity. In order to eliminate this risk, Europe of the $21^{\text {st }}$ century should be open to other cultural amalgamations and influences as the sources of its own strength and richness.

Keywords: Multiculturalism, Europe, minorities, integration, cultural pluralism

\section{$\ddot{O ̈ z e t:}$}

Özellikle yirmi birinci yüzyllın ilk yıllarından itibaren, çokkültürlülük kavramı Avrupa gündeminin en önemli araştırma konularından biri olarak önümüzde durmaktadır. Kavramin farkl yorumlarını ve bu yorumların akla getirdiği farklı çağrışımları da göz önünde bulunduran bu çalışma "-olumlu anlamda- çokkültürlü bir Avrupa mümkün müdür?" sorusuna yantt aramaktadır. Ülke örneklerine başvurularak elde edilen sonuçlar son

\footnotetext{
* "Multiculturalism in Europe" paper presented at Cosmopolitanism and Europe Conference, organised by Royal Holloway - University of London, Egham, April 22-23, 2004.

${ }^{* *}$ Dr., Marmara University, Faculty of Economics and Administrative Sciences, Department of Political Science and International Relations.
} 
zamanlarda sıklıkla kullanılan "çokkültürlülük söylem ve politikaları"nın hem Avrupa'da görülen farklı alt kültürlerin etkisizleştirilmesi hem de baskın kültürlerin kendi hakimiyetlerini sürdürebilmeleri için ortaya kullanıldı̆̆ını göstermektedir. Oysa böyle bir eğilim hem genelde Avrupa'nin hem de özelde (siyasi bir yapllanma olarak) Avrupa Birliği'nin kendi içine kapanmasına neden olacaktır. Bu gidişi önlemek için yirmi birinci yüzyll Avrupa'sının -kendi zenginliğinin kaynăğ olarak-farklı kültür ve etkileşimlere açık olması zaruridir.

Anahtar Kelimeler: Çokkültürlülük, Avrupa, azınllklar, entegrasyon, kültürel çoğulculuk

\section{Introduction}

The European political agenda has always been dominated by various topics under different circumstances. In the 1920s the inter-state rivalry and recovery from war were the widely discussed topics. In the 1930s the dominant issue was the rise of fascism and Nazism. It was the dawn of the cold war in the 1940s; the creation of new institutional structure and the beginnings of the European Union (EU) in the 1950s; the revolt against authority in the 1960s; stagnation amid the geo-political détente in the 1970s; nuclear fears, transatlantic tensions and east-west civic initiatives in the 1980s and post-cold war euphoria in the 1990s. The first years of the $21^{\text {st }}$ century witnessed the emergence of the topics of minorities; cultural, ethnic and religious plurality and diversity; tolerance and equality. As a result of the recent challenges to the modernist approach of nation building process and the weakening of the nation-states as the most powerful actors in international politics multiculturalism has emerged an alternative way of thinking and dominated the political spectrum of the European states.

Although multiculturalism has some positive connotations for the groups which are different from the majority of the society where they live, this study will try to show that it is only one side of the coin, while the other side may imply the justification and even legalisation of the assimilationist policies through multicultural discourses. In other words, this paper will try to answer whether multiculturalism would be possible in Europe. In doing this, the reference point will be the Turkish population in Germany. The first part, as the definitive part, will explore the meaning and implications of multiculturalism. The second part will examine the emergence of 
multicultural societies in Europe within the framework of the national responses to multiculturalism by focusing on the citizenship regulations of the Germany, France and the United Kingdom as three examples representing the European approaches. The third part will evaluate the situation of the Turkish population in Germany with references to its governmental policies.

\section{What is Multiculturalism}

The $20^{\text {th }}$ century has witnessed the re-emergence of different groups of people who have been oppressed by the majority of the society in which they live. This oppression is mostly seen because of their different historical roots, traditions and life-styles. In this framework, the native people, national minorities, ethno-cultural nations, old and new migrants, feminists and greens as some of them have led to the initiation of the new challenges to the traditional and well-established intellectual and political thoughts. As different from the conventional assumptions and thoughts, their common departure point depends on the resistance to the widespread homogenous policies and practices acknowledging the view that there is only one real and normal way to understand and construct all parts of the life (Parekh, 2002: 1). In most of the circumstances those different groups have suffered from to the assimilationist policies of the central governments and their rationalist, universalistic, egalitarian ideals, although they have been in favour of protecting their own cultures, traditions and beliefs. In this framework, with the rejection of the central and unitary character of the modern nation-state (Gülalp, 2003: 161), multiculturalism has appeared as an alternative political response to ensure a peaceful coexistence and a freer political system.

Despite being a controversial and contested concept, in a very general sense, arguments of multiculturalism are directed against "essentialist" or "monoist" definitions of nationality which assumes cultural homogeneity in the societies (Modood, 2000: 175). In essence, essentialism denies a historical reality of the interaction among different cultures. Moreover, modernist thinking has confined most of the universal values to the national boundaries and closed the dialog channels among different cultures. In parallel, anti-essentialist understanding defines multiculturalism as the "mosaic" of several bounded, nameable, individually homogenous and unmeltable minority uni-cultures which are pinned onto the backdrop of a similarly characterized majority uni-culture (Modood, 2000: 176). In that 
sense, ethnic identities are not simply accepted as given, static or atemporal identities. On the contrary, they are considered as dynamic ones changing under new circumstances and according to different social spaces which they share with other heritages and influences (Modood, 2000: 177). In this framework, multiculturalism implies a society or containing various cultures which are in a continuous interaction with each other. It also suggests a largeness of conception, a transcendence of sectional interests and openness to the variety of human pursuits and achievements Caws, 1996: 381). Under multiculturalism, single cultures may continue their existence in their pure forms. They can be aware of their own needs and are deemed to have the same right to exercise political power through the vote or through some other means. In this framework, in multicultural societies autantic cultures are regarded as equal to each other and cultural resources are revitalized in the name of diversity (Gülalp, 2003: 179). Therefore, as Peter Caws argues it the two key elements of multiculturalism are "the value of alternative cultures and their utility as vehicles for self-identification in the face of an oppressive dominant culture" (Caws, 1996: 373).

Multiculturalism in practice, however, can be read from two opposite dimensions. The first definition is based on the cultural essentialism and rejects any idea that cultures can change in time and interact with each other. By laying too much emphasis on the cultural relativism, it may imply a congregation-based model envisioning the co-existence of different cultures where each of them has the chance to survive within an autonomous area reserved for themselves (İnsel, 2001: 104). In segregated communities, people tend to define themselves within the framework of their collective existence and the isolated cultures which do not contact each other and consequently may lose communication among and influence from each other. As a result, each specific culture may become protective by building fences around themselves and lose any opportunity to know others (Aksoy, 2001: 53). This definition of multiculturalism implying the domination of the leading culture on other groups represents the exclusionist aspect of multiculturalism.

From the other perspective, on the other hand, multiculturalism is based on a sort of "melting pot" praxis deriving from the interaction among different cultures to encourage cultural enrichment (İnsel, 2001: 105). According to this understanding, throughout history, different cultures have not prospered within the boundaries of a single and particular culture. On 
the contrary, they have transcended national boundaries and influenced each other (Aksoy, 2001: 53). The interaction among different cultures may disturb the cultural purity of different groups and lead to the cultural intercourse among them. Such an understanding may easily lead to the creation of a cosmopolitan cultural sphere formulated by the groups, independent from their national, religious or similar affiliations (Laçiner, 2001: 161). This fact shows us that the modern cultures are no more identical and homogenous and the differences among various groups in the society should not prevent them from harmonious and peaceful coexistence. What is important here is the unifying impact of a composite culture formulated by deculturalisation (İnsel, 2001: 105). Thus, multicultural policy gives specific claims and status to different cultural groups within the society, in order to ensure that they will continue as distinct cultural groups rather than being assimilated into the dominant culture (Wallace and Shaw, 2002: 4).

It should not be forgotten that there is a delicate balance between multiculturalism on the one hand and assimilation and integration, on the other. Therefore, those concepts have to be clearly analysed. By referring to Tariq Modood's definitions, it can be recognised that "assimilation is a oneway process affecting relationship between social groups where the desired outcome for society as a whole is seen as involving least change in the ways of doing things of the majority of the country and institutional policies. Integration is a two-way process of social interaction where members of the majority community as well as immigrants and ethnic minorities are required to do something, so the latter cannot alone be blamed for failing to or not trying to integrate" (Modood, 2005). As different from them and with emphasis to cultural diversity, hybridity and fusion, multiculturalism implies a two-way process of integration which works differently for different groups implying a pluralistic integration (Modood, 2005). In that sense, for better treatment of the different cultural groups in the dominant culture -without assimilationist concerns-, it has to be acknowledged that the societies are plural and heterogeneous in today's world and this heterogeneity does not form an obstacle for a peaceful coexistence among its different parts. However, it is not always easy to accept the view that homogenous structure of the societies is no more existent and universal human rights are no more sufficient to satisfy the special needs and different claims of various groups living in those heterogonous societies. Moreover, even if those facts are accepted in theory, it is not sufficient by itself due to 
the need to transfer this rhetoric into the political arena which is not an easy task mainly due to the fear of the heterogeneous structures of the societies and the existence of "foreigners" living there.

Throughout history, the people had to leave their countries due to economic, political, social or religious reasons and search for a new home for themselves. But, new home which accepted them as "foreigner" or "Other" has always meant new difficulties and new restrictions for them (Aksoy, 2001: 51). Actually, the idea of foreigner has a long history. Although it has kept is validity in all periods, its meaning has changed. During the Renaissance period, there was a religious understanding in terms of ethical and intellectual framework. The non-European foreigners ("Other") were called as infidel. In the Enlightenment period, the main characteristic of the "Other" was his ignorance and superstition. In the $19^{\text {th }}$ century the reference point for the foreigner was development or evolutionary process. With the dissolution of the empires and the emergence of the nation-states, the meaning of the "Other" changed once more. In this period the national homogeneity principle emerged and any person who is not the citizen of the nation state because of his/her belonging to a different ethnicity, language, and religion or even to a different sect was regarded as the "Other" (Morley and Robins, 1997: 24).

When we have come to the $20^{\text {th }}$ century, the problem has complicated further. With the end of the colonization period, migration to those coloniser countries has intensified. The need for man-power increased in most of the European countries in the post World War II years which was the period of reconstruction and industrial growth. With the short of labour due to the disastrous effects of the war, foreign workers came to meet the need of domestic labour market. So, the European countries had to confront new waves of migration and the immigrant workers settled in the receiving societies raising serious economic, social and political challenges for integration. These people were always regarded as enemies and threats by the members of the majority. However, it has never been easy to find a convincing answer to the question why the West has accepted the "Other" always as a threatening factor in its own imagination (Morley and Robins, 1997: 24). On the other hand, as a response to their unfavourable treatment, the newcomers have always demanded the recognition of their own cultural and ethnic differences, when they became aware of the fact that the principle of "equal citizenship" can no more be sufficient to settle their 
problems. Instead, a different kind of citizenship a "pluralist, multilogical and dispersed one as amplifying a certain kind of politics" (Modood, 2007) has been accepted as an alternative way or a possible solution to improve the situations of the unequally treated people.

In this framework, the following chapter of this paper will focus on the citizenship practices of three countries, namely Germany, France and the United Kingdom, with the a reference to their compatibility with multicultural theory and practices.

\section{Multiculturalism in Europe}

\section{Historical Evaluation}

Historically, the West has assumed its superiority over other cultures and forced them to accept their inferiority. However, with increasing cultural diversity in Europe, Western centralization and superiority have lost its validity. Instead a "hybrid Europe in continual cultural flux" (Amin, 2002: 9) and multiculturalism has become the most constructive and morally sustainable way for public policy to engage with challenges posed by mass immigration movements starting in the post-World War II era (Wallace and Shaw, 2002, 3).

After the post World War II migration movements, West European countries found themselves in a position to find the ways of peaceful cohabitation of diverse cultural groups. Therefore, it can easily be claimed that ethnic and racial diversity after the war has become the central backdrop of multicultural claims (Joppke, 1998: 289). The migration movements which started in 1950s and 1960s with the guest workers continued in the form of family unification in 1970s. The situation has changed since the 1980 s when the integration of world economy, the globalisation of capital and labour and the rapid development of transport and communication networks have contributed to new types of migration movements As different from the older ones, the new types of migrant are characterised by their fragmented nature: they include new forms of flexible labour, insecure legal status, variable duration, new gender roles and multiple destinations (Triandafyllidou, Modood and Zapata-Barrero, 2006: 8). The implosion of the communist regimes in Central and Eastern Europe (CEE) in 1989 has made the new context even more volatile and dynamic due to the diverse 
forms of population movements from CEE to West Europe after the opening of the borders between the two sides. As a result the problem has become more problematic due to the complexity and differentiation of migrant communities in terms of their country of origin, entry status, educational levels, and skills. Large numbers of migrants have arrived, worked and stayed in most of the European countries and these have generated a much more differentiated migrant population in European states (Kofman, 2004: 4-5). The beginning of the new century, on the other hand, has been characterised by further developments mainly due to the complex picture of the new and old migrations as a result of the fluidity of the EU borders.

The historical perspective given above shows that Europe has to live together with the "other/foreigner" starting from the 1950s, although it was not an easy task for Europeans, as well as for the foreigners. European leaders had the concern about the adaptation of the new people to the existent political, economic and social structure. European labour was hesitant about the threat of deterioration of their life styles due to the existence of illegal labour force. For these reasons, migration was perceived as a threat to the cultural and societal values and to the basic determinants of Europe. Since if the governments could not build upon the multicultural tolerance within the society, but rather move quickly to define common national goals and to root out this targeting of minorities, xenophobia will be likely to emerge and make the new immigrant groups the victim of racist spleen (Watson, 2000: 36). Under those conditions, especially since the $1990 \mathrm{~s}$, multiculturalism has gained reputation as a political theory representing a critique and alternative to the traditional "assimilation" policies (Vassaf, 2002: 183-184), which assumes that the cultural differences imported into the receiving society by immigrants should and would be extinguished in the long run (Joppke, 1998: 289). With the recognition of different features of the post-war immigrants in comparison to their predecessors and their less homogenous and less hierarchically organised structure, it has become dangerous to neglect (or to reject) the challenge of developing a vision of organising diversity (Schiffauer, 2006: 112).

In this framework, on the theoretical side, we can identify some influential persons who are the proponents of diversity, pluralism and multiculturalism in the continent. Claude-Henri Saint-Simon, François-René de Chateaubriand, Heinrich Mann, Richard Nikolaus von Coudenhove- 
Kalergi, Milan Kundera are only a few of them all of which have agreed on the rejection of the imposition of Western values on other cultural groups. Accordingly, in stead of the domination of one common culture, a tolerant and peaceful Europe which accepts the diversity and differentiation of other cultures should be created (Lützeler, 2001: 6-8). Besides them, Jürgen Habermas should also be remembered within the framework of citizenship discussions which have a direct impact on the multicultural policies. Specifically, he is against the German ius soli principle in granting the citizenship status to the individuals as being against the strict tie between citizenship and national identity. He argues that democratic right of selfdetermination shall include the right to preserve one's own political culture which includes the concrete context of citizen's rights (Habermas, 1995: 258-259). Accordingly, only within the constitutional framework of a democratic legal system can different ways of life coexist equally and only democratic citizenship can prepare the way for a condition of world citizenship which does not close itself off within particularistic biases, and which accepts a worldwide political communication. In this framework, he argues that state citizenship and world citizenship form a continuum that already shows itself in outline form (Habermas, 1995: 278-279).

On the other hand, as an another important name, Will Kymlicka supports the idea of "multicultural citizenship" as a way of integration of different groups into the society and expression of their group-differentiated right (Kymlicka and Norman, 1995: 305). He suggests special protection for minorities in the name of universal human rights, and sees human rights at the same time as a criterion to avoid any potential misuse of these special rights (Lützeler, 2001: 5). The multicultural givens in contemporary Europe demand a dialogic relationship between the cultures of majorities and minorities; they demand a mutual openness toward the other and a readiness to undergo new synthesis (Lützeler, 2001: 5). According to this understanding, the protection of the minority rights in multicultural societies would not only strengthen the unity and cooperation among the members of this group and provide them moral support, but also provide them the means for collective political action (Rex, 2000: 61). As a result, the ability of different cultural groups to continue their different languages, religions and traditions within the dominant culture would provide them the opportunity to sustain their lives without being subject to any assimilationist policies. 


\section{National Responses}

As it can be recognised from the above discussions, the emergence of ethnic relations and immigration as a central issue within the European polities has especially been apparent since the 1990s with the emergence of migrants and minorities as the influential political actors in the continent (Koopmans and Statham, 2000b: 14). In this framework, concrete policy proposals and initiatives have been discussed under various platforms the most concrete example of which was the Amsterdam Treaty. It accepted the concepts such as migration, refugees, asylum-seeker or migrant citizenship as the prior subjects of the EU agenda. With the Amsterdam Treaty, the migration related concepts were moved from the third pillar to the first pillar and became one of the key issues of the Intergovernmental Conferences. However, in most of the cases the demands for these groups created tensions in the related countries and led to the strengthening of the xenophobic policies and racist attempt. That is why; from the 1990s, member states agreed on the restriction of the existing measures against the possible threats. In this framework, they accepted the strengthening of the external border controls, promotion of internal security cooperation, and devaluation of migrant rights to the level of common denominator of the participating member states (Koopmans and Statham, 2000b: 41). However, these policies implied the possibility of the process which might lead the EU to a "Fortress Europe" by minimizing its relations with the outside of Europe (Morley and Robins, 1997: 42). For this reason the European states are aware of the fact that the most important structural problem for them is to deal with the issue of the diversity of cultural groups and the possibility of their equal co-existence.

In this framework, John Rex divides national policies designed to cope with the issue into four categories which will be summarized below (Rex, 2000: 58-59). The first model demands the exclusion of immigrant minorities and their repatriation to the countries from which the immigrant generation had come. ${ }^{1}$ They are not tolerant to the existence of diverse groups. The second model implies the essentialist understanding of culture by arguing the fixity, traditionalist and unchanging character of the culture. Therefore, it refuses to recognise the separate existence of different groups. But it offers citizenship rights under the principle of jus soli to those born in

${ }^{1}$ Le Pen in France, Haider in Austria, and Vlaams Blok in Belgium. 
the country of immigrant settlement and to those immigrants who become naturalised. Although this option seems compatible with democracy, it may easily lead to total assimilation and violate the integrity and dignity of the cultural groups. The third model accepts the newcomers and their children as temporary residents. So, they are expected to turn back to their countries of origin. That is why the political citizenship rights are not entitled to these groups. Their rights are only dependent on the beneficent paternalistic concern of the related bodies, trade unions or churches. This model makes a difference between citizens with full political right and denizens without political rights. But among the others, the fourth alternative offers multiculturalism as a feasible solution in three different forms. It may envisage a total transformation of the culture of the society in which a national unitary culture is displaced by a new one which is more diverse and complex or hybrid; it may be based on the recognition of minority cultures and communities but involve negotiations with them to bring them under state control; or it may attempt to combine the recognition of cultural diversity with the promotion of individual equality (Rex, 2000: 59).

According to these policies, member states have tended to adopt different citizenship policies and models which are in direct relationship with the possibility of a multicultural Europe. In this context, we can mention about two principles of granting citizenship status which are influential in determining the degree and form of inclusiveness/exclusiveness. While the first one -jus sanguinis- with its emphasis on ethno-cultural attributes implies a more closed system, the second one -jus soli- has a more open and tolerant implications with its emphasis on civic and territorial attributes. On the other hand, citizenship policies and principles also determine the positions of the related government in terms of their inclinations towards either more assimilationist or more pluralistic approaches. Those which accept the assimilation as the ideal model policy vis-à-vis the foreigners can be considered as more demanding. On the other side, those which support cultural pluralism as the only way in dealing with diversity can be regarded as more accepting. By combining these dimensions three citizenship models can be identified in Europe; namely the ethno-cultural exclusionist (in Germany), civic assimilationist or republican (in France) and the multicultural pluralist (in the UK, Sweden, the Netherlands). The next part will summarize the impacts of the citizenship regimes of three countries -Germany, France and 
the UK as the main examples of the valid models within the European framework- on the conditions of their migrants and foreigners.

'Ethnic' or 'exclusive' citizenship model in Germany basing on linguistically and culturally unified group denies migrants' and their descendants' access to the political community or at least makes this access very difficult by way of high cultural or institutional barriers to naturalization. There, hundreds of thousand of German-born descendants of migrants are still officially "foreigner" (Ausländer) without any political rights (Koopmans and Statham, 2000a: 196). But on the contrary, ethnic German immigrants from the area of the former Soviet Union (Aussiedler) can obtain full political and social rights due to their hereditary link to the nation. In France, although it is relatively easy to acquire citizenship status, this does not mean that French community does not have any difficulty regarding their minorities who are required a high degree of assimilation in the public sphere and given little or no recognition to their cultural and religious difference through acquisition of citizenship by jus soli. In return of rights, migrant are expected to place loyalty to French republican values and political culture above allegiances to religious or cultural differences (Koopmans and Statham, 2000b: 19-20). Naturalisation laws were designed to make Frenchmen out of foreigners (Ireland, 2000: 237). On the other hand, migrants are provided with easy formal access to citizenship in the UK. Moreover they are recognized as ethnic minorities together with their own cultural rights and privileges (Koopmans and Statham, 2000a: 196). The differences in the citizenship models have also forced those countries to apply different labels to the migrants in their countries. They are foreigners in Germany, immigrants in France and ethnic minorities in Britain. Those citizenship policies also prove that multicultural discourses and practices would be more feasible and possible in the UK in comparison to other two examples. Among others, in the following chapter the German case will be analysed from a more detailed perspective with a specific reference to the Turkish people living there.

\section{Turkish Population in Germany}

Germany is a country which has historically been open to migration movements and searched for appropriate policies to deal with the issue of foreigner within its boundaries. The presence of recent immigrant populations makes legitimate claims for recognition which propel a debate on multiculturalism into the public sphere, although it is difficult to 
guarantee it. ${ }^{2}$ In this sense, those who campaign for multiculturalism had to show that the recognition of cultural diversity was compatible with and did not undermine those institutions which were concerned with guaranteeing equality between individuals and classes (Rex, 1996: 120).

Germany never accepted that it is an immigration country. New comers have always been considered as temporary residents who would return to their home countries in the future. Primarily, multiculturalism in Germany is for Germans themselves about the meaning of "Germanness". Only secondarily is it about migrants and foreigners (Joppke, 1998: 300). In the country, the migrants ${ }^{3}$-under the label of foreigner- have only a marginal role in the political arena mainly due to the exclusivist citizenship law (Koopmans and Statham, 2000a: 199). Although the people with nonGerman origin can easily be accepted to the labour market, they can not participate in the political arena. The institutional mechanisms for their political participation could not be formed and their involvement has always been prevented. Therefore, Germany is one of the best examples of the ethnoculturally exclusionist citizenship regimes which impose a strong and powerful distinction between "us" and "them" (Joppke, 1998: 301). The Christian Democrats are quite powerful to continue this understanding and to keep the characteristics of the German "high culture" alive. This approach, however, makes the acceptance of multiculturalism more difficult even at the theoretical level. But on the other hand there are also some other political groups, i.e. the Greens or most of the Social Democrats which support and encourage cultural plurality by defending the rights of the migrants and refugees.

In Germany, specifically Turkish migrants are important to understand the exclusivist tendencies and policies of German government. Although Turkish immigration was encouraged at the beginning due to the practical reasons, their existence was initially perceived as a temporary measure to cope with labour shortage problem (Watson, 2000: 33). Guest workers were expected to return back when their jobs were done and once their contracts had expired. But over time it was understood that it is something permanent

\footnotetext{
${ }^{2}$ Legally, the provisions of the related treaties and the regulation in European legislation are not adequate to implement such kind of a policy.

${ }^{3}$ They are mostly the people who came from Turkey. Former Yugoslavia, Italy, Greece and Poland are some other countries exporting migrants to Germany.
} 
or semi-permanent despite the lack of attempts to encourage their integration with the society without forced assimilation. Thus, each side has become aware of the fact that they were culturally separate and Turkish society in Germany is an inclusive and inward-looking oriented one (Watson, 2000: 33-34). Although German governments provide some public services to Turkish migrants, i.e. school service for children or German language learning opportunities, they are always accepted as the means of German governments to serve the interests and benefits of Germany. To be more specific, it can be argued that the "foreigners" would become familiar with the system and could contribute efficiently to the running of the economy through those services.

As it is common to all migrant communities, another problem for the Turkish migrants is the lack of their political rights and the obstacles for them to become active members of the democratic society. They do not have any institutionalized channels of access to the political process. As it can be understood from a speech by Helmut Kohl, integration for them only means peaceful existence in the society, but not being a citizen. However, the inclusiveness of Turkish society mentioned above underlines the distinction between the Turkish migrants and the societies of the countries where they live. It also emphasizes something contrary to Kohl's argument; integration should not mean just to settle down. On the contrary, interaction between two sides is important for a peaceful co-existence. In this framework, inadequate answers to the demands of migrant societies might force these groups facing with the discriminatory policies of the dominant culture to become much more conservative and authoritarian to preserve their own cultures. As a response to the governmental and legal measures, they might strengthen their nationalistic or religious ties to defend themselves. As an example, after a change in the German citizenship law which provided the right to acquire German citizenship, but only after leaving their Turkish nationality, only a limited number of Turks applied to be a German citizen. This situation proves the reservations and concerns of a total integration into the dominant culture from the perspective of the minority groups in general and the Turkish migrants in particular.

In recent years, the exclusionist tendencies in German society have intensified due to the deterioration in economic, social and structural conditions of the country, especially after the unification of West and East Germany. The foreigners have been seen as the only responsible and main 
scapegoat of the all kinds of problems (Watson, 2000: 34). These factors have also led to the strengthening of discrimination against foreigners in the society.

\section{Conclusion}

The examples of West European countries have shown us that the policies and mechanisms developed by them for the treatment of foreigners in their own countries are from being efficient and sufficient for foreigners themselves. On the contrary, they have produced unfavourable results for the foreigners which have made them more and more protective and inwardlooking due to the fences they have built around themselves. Therefore, it can be argued that the recent multicultural discourses have appeared as a new kind of nationalism to preserve the dominance of the nation-states by strengthening its culturalisation policies. In other words, multiculturalism has recently implied the domination of the leading culture on other groups and represents the discriminatory and exclusive aspects of the concept by making the other as exotic (Kaya, 2003: 17) which makes them dependent on the interest, support and preservation of the majority. Accepting the minorities in terms of their folkloric rights and demands but disregarding their participation in the societal life have created a societal inequality, exclusion and discrimination for the inferior other due to their needs for the tolerance of the majority and creates a power relation by putting the majority at a privileged and superior position as compared to the minority. This situation, however, reduces the minority groups into cultural differences without providing any opportunity in economic, social or political aspects of the life.

Considering these theoretical perspectives, we can identify two Europes; namely the "conservative Europe" which is a holistic one implying that religious, ethnic, historical and traditional baggage of the people is of utmost importance for the European integrity and a more dynamic and open-minded Europe where diversity, difference and plurality are far more important than the past, culture, tradition or heritage. Considering the racist and extremist movements and practices in the European societies, it can be argued the first model is the dominant and valid one for the presence and it is undermining the hopes and prospects for a more diverse and plural Europe. Considering the fact that [Europe] would gain its power from a multicultural whole forming various groups (Vassaf, 2002: 219-220), it is a must for Europe to revitalize its dynamics to embrace all kinds of diversities 
in the continent. Actually, it has to be recognised that the historically dominant view that "West is West and East is East and these two groups can never be joined together" would loose its validity in time (Vassaf, 2002: 280). On the contrary, the existence of the foreigners in the continent will inevitably create a synthesis of the East and West with the help of the dynamic nature of Europeanness process.

As conclusion, it should also be emphasised that Europeanness is not a static concept with clear cut boundaries. It has always been structured and restructured. In this context, the harmonious coexistence among various groups has become unavoidable, even if it is a difficult task. At this stage, what is important is to promote and encourage "inter-culturalism" as the expression of cultural and ethnic differences in public space as well and the solution of the problems emerging from differences by intercultural dialogue. Considering the fact that an inward-oriented nature of the EU would clearly limit its prospects of playing the role of a genuinely global actor, ethnically and religiously mix Europe of the $21^{\text {st }}$ century which is open to other cultural amalgamations and influences would be more preferable by all of its members as a source of their strength and richness.

\section{References:}

Aksoy, N. (2001). 'On Multiculturalism'. Modernity and Multiculturalism. İstanbul: İletişim Yayınları.

Caws, P. (1996). "Identity: Cultural, Transcultural, and Multicultural". D. T. Goldberg (ed.), Multiculturalism: A Critical Reader. Oxford: Blackwell Publishers.

Gülalp, H. (2003). Kimlikler Siyaseti, Türkiye'de Siyasal İslamin Temelleri (The Politics of Identity, The Roots of the Political Islam in Turkey). İstanbul: Metis Yayınları.

Habermas, J. (1995). 'Citizenship and National Identity: Some Reflections on the Future of Europe'. R. Beiner (ed.), Theorizing Citizenship. New York: State University of New York Press.

Ireland, P. (2000). 'Reaping What They Sow: Institutions and Immigrant Political Participation in Western Europe'. R. Koopmans and P. Statham 
(eds.), Challenging Immigration and Ethnic Relations Politics, Comparative European Perspectives. Oxford: Oxford University Press.

İnsel, A. (2001). 'Multi-Culturalism, Multiple Identity and Pluralism'. Modernity and Multiculturalism. İstanbul: İletişim Yayınları.

Joppke, C. (1998). 'Multiculturalism and Immigration: A Comparison of the United States, Germany and Great Britain'. D. Jacobson (ed.), The Immigration Reader: America in a Multidisciplinary Perspective. Massachussets: Blackwell Publishers.

Kaya, A. (2003). 'Ulusal Yurttaşlıktan Çoğul Yurttaşlığa' ("From National Citizenship to Plural Citizenship"). A. Kaya and G. G. Özdogan (eds.), Uluslararası Ilişskilerde Sınır Tanımayan Sorunlar (Transboundary Issues in International Relations). İstanbul: Bağlam Yayıncılık.

Kofman, E. (2000). 'Contemporary European Migrations, Civic Stratifications and Citizenship'. Paper presented at International Migrations: New Patterns, New Theories. Nottingham Trend University.

Koopmans, R. and Statham, P. (2000a). 'Challenging the Liberal NationState? Postnationalism, Multiculturalism, and the Collective Claimsmaking of Migrants and Ethnic Minorities in Britain and Germany'. R. Koopmans and P. Statham (eds.), Challenging Immigration and Ethnic Relations Politics, Comparative European Perspectives. Oxford: Oxford University Press.

Koopmans, R. and Statham, P. (2000b). 'Migration and Ethnic Relations as a Field of Political Contention: An Opportunity Structure Approach'. R. Koopmans and P. Statham (eds.), Challenging Immigration and Ethnic Relations Politics, Comparative European Perspectives. Oxford: Oxford University Press.

Kymlicka, W. and Norman, W. (1995). 'Return of the Citizen: A Survey of Recent Work on Citizenship Theory'. R. Beiner (ed.), Theorizing Citizenship. New York: State University of New York Press.

Laçiner, Ö. (2001). 'Multiculturalism'. Modernity and Multiculturalism. İstanbul: İletişim Yayınları.

Lützeler, P. M. (2001). 'Towards a Multicultural European Identity: Historical Perspectives and Contemporary Developments'. AICGS Humanities, 10, 1-15. 
Modood, T. (2007). Multiculturalism, Citizenship and National Identity. Retrieved: $\quad$ November 11, 2008, from http://www.opendemocracy.net/faitheurope_islam/multiculturalism_4627.jsp.

Modood, T. (2005). Remaking Multiculturalism after 7/7. Retrieved: November 11, 2008, from http://www.opendemocracy.net/conflictterrorism/multiculturalism_2879.jsp.

Modood, T. (2000). 'Anti-Essentialism, Multiculturalism and the 'Recognition' of Religious Groups'. W. Kymlicka and W. Norman (eds.), Citizenship in Diverse Societies. Oxford: Oxford University Press.

Morley, D. and Robins, K. (1997). Kimlik Mekanları, Küresel Medya, Elektronik Ortamlar ve Kültürel Sinirlar (Identity Spaces, Global Media, Electronic Atmosphere and Cultural Boundaries). İstanbul: Ayrınt1 Yaymları.

Parekh, B. (2002). Çokkültürlülüğ̈̈ Yeniden Düşünmek, Kültürel Çeşitlilik ve Siyasi Teori (Rethinking of Multiculturalism, Cultural Diversity and Political Theory). Ankara: Phonix Yayınevi.

Rex, J. (2000). 'Multiculturalism and Political Integration in Europe'. R. Koopmans and P. Statham (eds.), Challenging Immigration and Ethnic Relations Politics, Comparative European Perspectives. Oxford: Oxford University Press.

Rex, J. (1996). Ethnic Minorities in the Modern Nation State. Warwick: Centre for Research in Ethnic Relations.

Schiffauer, W. (2006). 'Enemies within the Gates - The Debates about the Citizenship of Muslims in Germany'. T. Modood, A. Triandafyllidou and R. Zapata-Barrero (eds.), Multiculturalism, Muslims and Citizenship - A European Approach. London and New York: Routledge.

Triandafyllidou, A., Modood, T. and Zapata-Barrero, R. (2006). 'European Challenges to Multicultural Citizenship: Muslims, Secularism and Beyond'. T. Modood, A. Triandafyllidou and R. Zapata-Barrero (eds.), Multiculturalism, Muslims and Citizenship - A European Approach. London and New York: Routledge. 
Vassaf, G., Daha Sesimizi Duyurmadık, Almanya'da Türk İş̧i Çocukları (We Haven't Yet Made Our Voices to be Heard, Turkish Guests' Children in Germany. İstanbul: Bilgi Üniversitesi Yayınları.

Wallace, C. and Shaw, J. (2002). Education, Multiculturalism and the EU Charter of Rights. Constitutionalism Web-Papers, ConWEB, 5, 1-18. Retrieved: October 31, 2008, from http://les1.man.ac.uk/conweb.

Watson, C. W. (2000). Multiculturalism. Buckingham: Open University Press. 